\title{
EDUKASI PENERAPAN PROTOKOL KESEHATAN \\ DALAM PENCEGAHAN COVID-19 PADA RELAWAN DI WILAYAH KERJA MEDAN
}

DOI: https://doi.org/10.33024/jkpm.v4i5.3935

\author{
Eva Kartika Hasibuan ${ }^{1 *}$, Yunida Turisna O. Simanjuntak ${ }^{2}$, Lia Rosa V. Sinaga ${ }^{3}$ \\ ${ }^{1}$ Program Studi Ners Universitas Sari Mutiara Indonesia \\ 2 Program Studi D3 Keperawatan Universitas Sari Mutiara Indonesia \\ ${ }^{3}$ Program Studi Kesehatan Masyarakat Universitas Sari Mutiara Indonesia
}

Disubmit: 02 Maret 2021 Diterima: 21 April 2021 Diterbitkan: 30 September 2021

Email Korespondensi: evakartikahsb86@gmail.com

\begin{abstract}
ABSTRAK
Wabah penyakit coronavirus 2019 (Covid-19) ini telah menciptakan krisis kesehatan global yang telah memiliki dampak yang mendalam pada cara kita memahami dunia dan kehidupan kita sehari-hari. Langkah-langkah untuk pencegahan juga telah dilakukan oleh pemerintah untuk dapat menyelesaikan kasus luar biasa ini, seperti menyosialisasikan gerakan physical distancing, stay at home, memakai masker saat keluar rumah dan menerapkan protokol kesehatan. Tujuan pengabdian ini yaitu terciptanya para relawan sebagai perpanjangan tangan untuk memutus rantai copid 19 melalui pos gagah yang telah dibekali materi terkait adaptasi kebiasaan baru dalam penerapan protokol kesehatan. Adapun metode yang dilakukan dalam pengabdian ini yaitu dengan memberikan edukasi penerapan protokol kesehatan dalam pencegahan copid 19 kepada relawan sebagai utusan dari masing-masing kecamatan di wilayah kerja Medan dalam bentuk pelatihan. Hasil dari pengabdian ini yaitu terjalinnya komitmen dalam membangun kesepakatan, bekerja bersama, saling mendukung dan melengkapi antara pemerintah, akademisi, dunia usaha dan komunitas masyarakat dalam memutus mata rantai penularan Covid-19, kemudian melalui pos gagah terbentuknya tim relawan yang akan memperkuat Satgas Covid-19 dalam menegakkan protocol kesehatan melalui edukasi, sosialisasi dan mitigasi. Diharapkan setelah dilakukan pelatihan, peserta (calon relawan) dapat menjadi agen perubahan di lingkungan keluarga, masyarakat dan tempat-tempat publik.
\end{abstract}

Kata Kunci: Protokol Kesehatan, Pos Gagah, Penularan Covid-19

\begin{abstract}
The 2019 coronavirus disease (Covid-19) outbreak has created a global health crisis that has had a profound impact on how we understand the world and our daily lives. Measures for prevention have also been taken by the government to be able to resolve this extraordinary case, such as socializing the physical distancing movement, staying at home, wearing a mask when leaving the house and implementing health protocols. The aim of this service is the creation of volunteers as an extension of the hand to break the chain of copid 19 through dashing posts that have been provided with materials related to the adaptation
\end{abstract}


of new habits in the application of health protocols. The method used in this service is by providing education on the application of health protocols in the prevention of copid 19 to volunteers as representatives from each sub-district in the Medan working area in the form of training. The result of this service is a commitment to building agreements, working together, supporting and complementing the government, academia, business world and the community in breaking the chain of Covid-19 transmission, then through a dashing post a volunteer team is formed to strengthen the Covid-19 Task Force. 19 in enforcing health protocols through education, outreach and mitigation. It is hoped that after the training, participants (volunteer candidates) can become agents of change in the family, community and public places.

Keywords: Health protocol, Prevention and Control Posts, Covid-19 Transimission

\section{PENDAHULUAN}

Corona virus merupakan keluarga besar virus yang menyebabkan penyakit mulai dari gejala ringan sampai berat. Ada setidaknya dua jenis corona virus yang diketahui menyebabkan penyakit yang dapat menimbulkan gejala berat seperti Middle East Respiratory Syndrome (MERS) dan Severe Acute Respiratory Syndrome (SARS). Corona Virus Disease 2019 (Covid-19) adalah penyakit jenis baru yang belum pernah diidentifikasi sebelumnya pada manusia. Virus penyebab Covid-19 ini dinamakan SarsCoV-2 (Depkes, 2020).

Akhir tahun 2019 dunia dikejutkan dengan adanya new emerging infectious disease di China yang disebabkan oleh Coronavirus Disease (Covid-19). Hal ini mengingatkan pada kejadian 17 tahun yang lalu, dimana wabah Severe Acute Respiratory Syndrome (SARS) muncul pertama kali di China. Jika dilihat dari tingkat kematian akibat virus tersebut (Case Fatality Rate atau CFR), CFR Covid-19 lebih rendah dibandingkan dengan CFR SARS, yaitu sebesar 2\% sedangkan SARS mencapai 10\%. Walaupun CFR lebih rendah tetapi kasus Covid19 berkembang dengan cepat dan telah menyebar di 27 negara lainnya (Goyena \& Fallis, 2019).

Berdasarkan data Gugus Tugas Percepatan Penanganan (GTPP) Covid-19 Sumatera Utara (Sumut), sebanyak 76\% kasus Covid-19 disumbang oleh wilayah Medan, Binjai dan Deli Serdang (Mebidang). Ketiga daerah ini menjadi perhatian dalam penanganan penyebaran Covid-19 karena posisinya berdekatan, bahkan seperti tidak memiliki batas dan mobilitas masyarakat di ketiga daerah ini cukup tinggi. Terhitung pada Agustus 2020 pasien terkonfirmasi positif Covid-19 di Medan berjumlah 2.386 orang, PDP 291 orang, sembuh 932 orang dan meninggal 106 orang. Kota Binjai, pasien terkonfirmasi positif 64 orang, PDP 4 orang, sembuh 21 orang dan meninggal 5 orang. Sementara di Deli Serdang, pasien terkonfirmasi positif berjumlah 522 orang, PDP 45 orang, sembuh 190 orang dan 37 orang meninggal (humas.sumutprov.go.id).

Wabah penyakit coronavirus 2019 (Covid-19) ini telah menciptakan krisis kesehatan global yang telah memiliki dampak yang mendalam pada cara kita memahami dunia dan kehidupan kita sehari-hari (Frontiers, 2020). Langkahlangkah untuk pencegahan juga telah dilakukan oleh pemerintah untuk dapat menyelesaikan kasus luar biasa ini, seperti menyosialisasikan gerakan physical distancing, stay at home, memakai masker saat keluar rumah dan menerapkan protokol kesehatan (Kemenkes, 2020). 
Upaya preventif sejauh ini merupakan praktik terbaik untuk mengurangi dampak pandemi covid 19, mengingat belum adanya pengobatan yang dinilai efektif dalam melawan virus SARS-CoV-2. Saat ini, tidak adanya vaksin untuk SARS-CoV-2 yang tersedia dan telah memenuhi berbagai fase uji klinis, sehingga upaya preventif terbaik yang dilakukan adalah dengan menghindari paparan virus dengan didasarkan pada PHBS (Perilaku Hidup Bersih dan Sehat). Untuk mencapai tujuan ini, langkah-langkah utama yang hendak dilaksanakan masyarakat seperti penggunaan masker; menutup mulut dan hidung saat bersin ataupun batuk; mencuci tangan secara teratur dengan sabun atau desinfeksi dengan pembersih tangan yang mengandung setidaknya $60 \%$ alkohol; menghindari kontak dengan orang yang terinfeksi; menjaga jarak dari orang-orang; dan menahan diri dari menyentuh mata, hidung, dan mulut dengan tangan yang tidak dicuci, ( $\mathrm{Di}$ Gennaro et al., 2020).

Covid-19 sangat mudah dan cepat menular, sehingga pemerintah berupaya keras untuk menanggulangi penyebaran Covid-19 ini. Sampai saat ini belum meratanya lapisan masyarakat yang mendapatkan vaksin untuk masalah ini sehingga jalan satu-satunya hanyalah memutus mata rantai penyebaran Covid19 ini, untuk itu hingga saat ini, kita masih dituntut untuk terus berada di rumah saja karena tingkat persebaran virus Corona baru belum juga menyusut. Melakukan karantina mandiri di rumah, merupakan salah satu solusi terbaik jika tak ingin tertular Covid-19. Sayangnya, banyak orang mengeluh bosan karena sudah berminggu-minggu lamanya hanya berada di rumah saja. Inilah yang membuat beberapa orang nekat jalan-jalan dan keluar rumah, padahal pemerintah setempat sudah banyak yang menerapkan Pembatasan Sosial Berskala Besar (PSBB) (Meihartati T, 2020).

Pandemi Covid-19 telah membawa perubahan besar dalam tatanan kehidupan manusia. Pemerintah telah dengan tegas mengeluarkan berbagai kebijakan di segala bidang. Salah satunya di bidang pendidikan, siswa terpaksa harus belajar dari rumah dengan melakukan pola pembelajaran jarak jauh (Remote Teaching) (Karma, 2020). Kebijakan senyatanya ingin mengatasi masalah yang terjadi, tetapi di sisi lain juga memunculkan persolan-persoalan yang baru dan hampir dirasakan oleh seluruh masyarakat saat ini didaerah manapun.

Saat ini, respon masyarakat untuk berpartisipasi aktif dalam pencegahan penyebaran Covid-19 dengan mematuhi himbauan pemerintah untuk menjalankan protokol kesehatan belum cukup optimal (Buana, 2020). Masih banyak masyarakat yang masih lalai dalam memperhatikan protokol kesehatan terlebih di Era New Normal ini.

Di situasi dan kondisi saat ini, kesadaran seluruh masyarakat untuk patuh dan taat dalam menjalankan protokol kesehatan memiliki peranan yang signifikan, sehingga perlu ditekankan kepada seluruh masyarakat untuk mematuhi protokol Covid-19 agar mengurangi penyebaran virus di pasar. Kebiasaan memakai masker bukan hanya keluar rumah, namun juga saat beraktivitas di luar, terlebih bagi para pedagang yang ada di pasar-pasar tradisional, sangat penting untuk tahu kemudian peduli terhadap diri sendiri dan lingkungan sekitar. Masyarakat punya andil dalam memutus rantai penyebaran Covid-19 dengan langkah kecil seperti memakai masker (Syapitri, H., Siregar, L. M., \& Saragih, F. L, 2020).

Untuk itu, diperlukan Sosialisasi dan Edukasi untuk meningkatkan pemahaman masyarakat (relawan) pentingnya memperhatikan protokol kesehatan dalam melaksanakan aktivitas. Sosialiasasi dan edukasi SarCov19 ini merupakan kunci utama keberhasilan penanganan pandemik Covid-19. 
Sosialiasasi dan Edukasi tentang Covid-19 sering diberikan oleh pemerintah. Namun, edukasi dan sosialisasi ini masih belum berjalan optimal di beberapa daerah.

Seiring dengan sosialisasi dan edukasi tentang Covid 19 yang telah dilakukan pemerintah, cara lainnya adalah dengan dibentuknya Pos Gagah Penanganan Pandemi Covid-19 Provinsi Sumut yang diadakan Badan Nasional Penanggulangan Bencana (BNPB) bersama Badan Penanggulangan Bencana Daerah (BPBD) Provsu. Gubsu H Edy Rahmayadi meminta kehadiran relawan melalui Pos Gabungan Pencegahan Covid-19 bisa menjadi perpanjangan tangan pemerintah. "Pandemi ini harus kita hadapi bersama-sama. Mudah-mudahan dengan adanya kehadiran relawan ini maka lebih baik lagi penanganan Covid-19 Sumut," ujar Gubsu. Deputi Bidang Pencegahan BNPB Lilik Kurniawan menjelaskan bahwa Pos Gagah merupakan langkah pencegahan penyebaran Covid-19 dengan mengedukasi masyarakat oleh para relawan yang telah mengikuti pelatihan. "Sumut merupakan salah satu dari 9 provinsi prioritas penanganan Covid-19. Untuk itu, pelatihan relawan ini merupakan upaya membantu penanganan Covid-19. Dimana Sumut merupakan Pos Gagah yang kedua dilakukan setelah Surabaya. Pos Gagah dilakukan di beberapa provinsi yang memiliki angka pandemi Covid-19 tertinggi, dan Pos Gagah yang kedua ini didirikan di Universitas Sari Mutiara Indonesia.

\section{MASALAH}

Pos Gagah dilakukan di beberapa provinsi yang memiliki angka pandemi Covid-19 tertinggi, Pos Gagah Penanganan Pandemi Covid-19 Provinsi Sumut yang diadakan Badan Nasional Penanggulangan Bencana (BNPB) bersama Badan Penanggulangan Bencana Daerah (BPBD) Provsu bekerjasama dengan Universitas Sari Mutiara Indonesia, yang sekaligus merupakan tempat dilakukannya pengabdian masyarakat dengan melibatkan relawan melalui Pos Gabungan Pencegahan Covid-19 di Universitas Sari Mutiara Indonesia yang menjadi perpanjangan tangan pemerintah dengan mengedukasi masyarakat/para relawan yang telah mengikuti pelatihan. Adapun tujuan umum dalam kegiatan ini yaitu Edukasi Penerapan Protokol Kesehatan Dalam Pencegahan Covid-19 Pada Relawan Di Wilayah Kerja Medan berjalan optimal dan tujuan khusus antara lain terbentuknya relawan dari berbagai kalangan (tokoh masyarakat, karang taruna dan dari aparat desa) di wilayah kerja Medan sebagai perpanjangan tangan di masyarakat untuk mensosialisasikan penerapan protokol kesehatan dalam pencegahan COPID 19 dan meningkatnya pengetahuan relawan dari berbagai kalangan (tokoh masyarakat, karang taruna dan perwakilan dari aparat desa) terkait protokol kesehatan dalam pencegahan COPID 19.
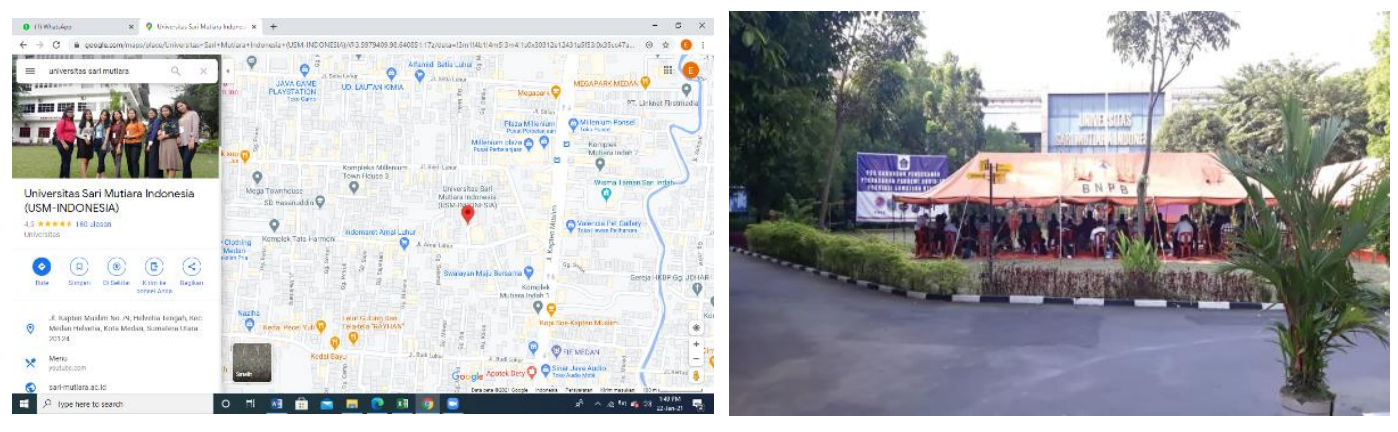

Gambar 2.1 Lokasi Pengabdian Masyarakat 


\section{METODE}

Adapun metode yang digunakan dalam pengabdian masyarakat ini yaitu dengan memberikan penyuluhan kesehatan berupa edukasi penerapan protokol kesehatan dalam pencegahan covid 19 kepada relawan sebagai utusan dari masing-masing kecamatan di wilayah kerja Medan dalam bentuk pelatihan, dimana peserta (relawan) akan menjadi agen perubahan dalam adaptasi kebiasaan baru terkait protokol kesehatan dengan melalui berbagai tahapan, antara lain:

1. Tahap Persiapan

Adapun tahapan persiapan yaitu persiapan pre planning, pembagian kelas dan nama-nama fasilator yang akan memberikan edukasi kepada masyarakat (relawan) dalam pelatihan adaptasi kebiasaan baru terkait protokol kesehatan, penyiapan materi, alat dan tempat

2. Tahapan Pelaksanaan

Sebelum fasilitator memberikan edukasi ke masyarakat (relawan) tentang pencegahan covid 19, fasilitator dibekali pengetahuan secara spesifik terkait adapatasi kebiasaan baru / protokol kesehatan dan menadatangani komitmen sebagai relawan setelah itu fasilator mendapatkan jadwal untuk memberikan edukasi pada relawan yang merupakan utusan dari masing-masing kecamatan di wilayah Medan. Pelatihan dilaksananakan dalam 10 hari, dibagi dalam 2 sesi (pagi dan siang hari) serta dibagi dalam 4 kelas. Namun pada pelaksanaan pengadian masyarakat ini, terkait edukasi protokol kesehatan penulis melaksanakannnya dalam 3 hari yaitu terhitung tanggal 25, 26 dan 27 September 2021.

3. Evaluasi

a. Struktur

Peserta hadir sebanyak 25 orang yang terdiri dari laki - laki dan perempuan. Setting tempat sudah sesuai dengan rencana yang dibuat dan perlengkapan yang dilakukan untuk pelatihan sudah tersedia dan sudah digunakan sebagaimana mestinya. Penggunaan bahasa yang disampaikan saat pemberian edukasi penerapan protokol kesehatan dalam pencegahan copid 19 sudah komunikatif dalam penyampaiannya, sehingga masyarakat (relawan) memahami materi dalam adaptasi kebiasaan baru terkait protokol kesehatan.

b. Proses

Pelaksanaan kegiatan dalam pengabdian masyarakat ini berlangsung pada tanggal 25, 26 dan 27 September 2021 dari pukul 09.00 s/d 10.30 WIB pada sesi 1 dan sesi $213.00 \mathrm{~s} / \mathrm{d} 14.30$ WIB sesuai dengan jadwal dan kelas yang telah direncanakan sebelumnya

c. Hasil

Hasil yang diharapkan terkait edukasi penerapan protokol

kesehatan, yaitu:

1. Peserta dapat memahami maksud dan tujuan

2. Peserta dapat memahami latar belakng

3. Peserta dapat memahami penjelasan Covid 19

4. Peserta dapat memahami adaptasi kebiasaan baru tepatnya terkait penerapan protokol kesehatan

5. Peserta dapat memahami kesiapsiagaan masyarakat terhadap bencana alam pada masa pandemi 


\section{HASIL DAN PEMBAHASAN}

a. Hasil

Kegiatan dalam pengabdian masyarakat ini dilakukan dalam bentuk pelatihan yang dikuti oleh masyarakat yang dalam pelatihan ini dinamakan relawan yang terdiri dari tokoh masyarakat, karang taruna dan perwakilan aparat desa, dimana tahap awal para relawan diminta untuk kesediaan dalam komitmen penuh menjadi relawan yang sebelumnya Gubernur Sumatera Utara H Edy Rahmayadi yang dalam kata sambutan nya dalam POS GAGAH di USM Indonesia menegaskan untuk memutus mata rantai COPID 19 bukan hanya tanggung jawab saya tapi merupakan tanggung jawab bersama, untuk itu diperlukan komitmen untuk menjadi agen pembaharu dalam memutus mata rantai penularan Covid-19.
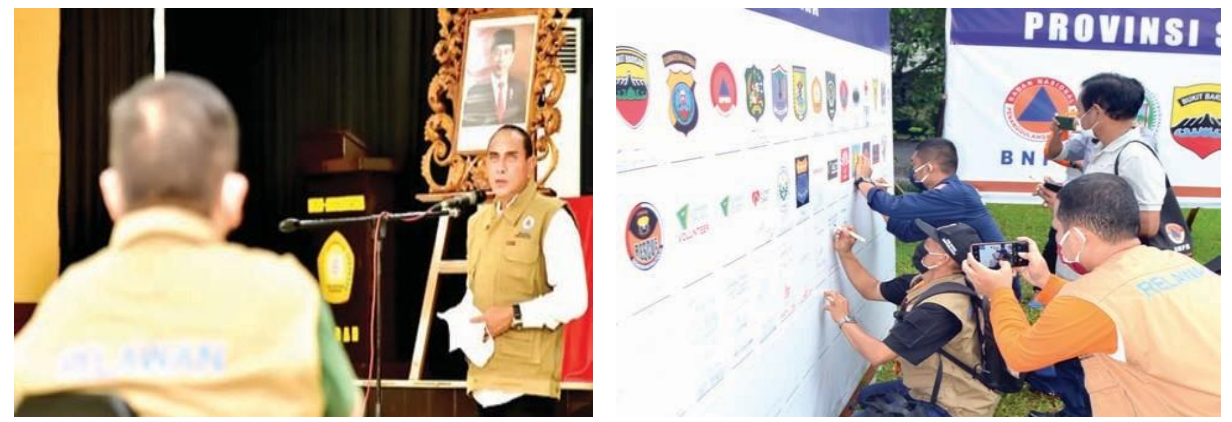

Gambar 4.1 Penandatanganan Komitmen Para Relawan

Pelatihan dilaksananakan dalam 10 hari, dibagi dalam 2 sesi (pagi dan siang hari) serta dibagi dalam 4 kelas. Namun pada pelaksanaan pengadian masyarakat ini, terkait edukasi protokol kesehatan penulis melaksanakannnya dalam 3 hari yaitu terhitung tanggal 25, 26 dan 27 September 2021. Tahap awal setelah relawan menandatangani komitmen, selanjutnya peserta pelatihan dibekali "Buku Saku Pencegahan Masyarakat Produktif dan Aman Covid-19". Materi yang diberikan meliputi informasi dasar Covid-19 serta pencegahannya, protokol relawan, keamanan dan pengamanan, serta penggunaan aplikasi inarisk.

Kegiatan pelatihan ini dilaksanakan dengan menerapkan protocol kesehatan, dimana para peserta diberikan masker, handsinitizer dan tetap menjaga jarak. Kegiatan ini dilakukan menggunakan sistem shift per harinya dan sesuai dengan jadwal yang telah ditentukan untuk wilayah Medan yang dilaksanakan pada pagi dan siang hari dengan kapasitas ruangan yang telah dibatasi yaitu 25 peserta per kelas. Selanjutnya peserta pelatihan mendapatkan materi terkait adaptasi kebiasaan baru dalam penerapan protokol kesehatan dari masing-masing fasilitator.

Keberhasilan program pengabdian masyarakat dalam bentuk pelatihan ini, saat sesi diskusi peserta sangat antusias dalam menanyakan hal-hal copid 19 dan adaptasi kebiasaan baru dalam penerapan protokol kesehatan, dan saat dilaksanakan evaluasi terkait materi yang telah disampaikan, peserta ataupun relawan dengan cepat dan tegas menjelaskan setiap pertanyaan yang dilontarkan oleh fasilitator. 

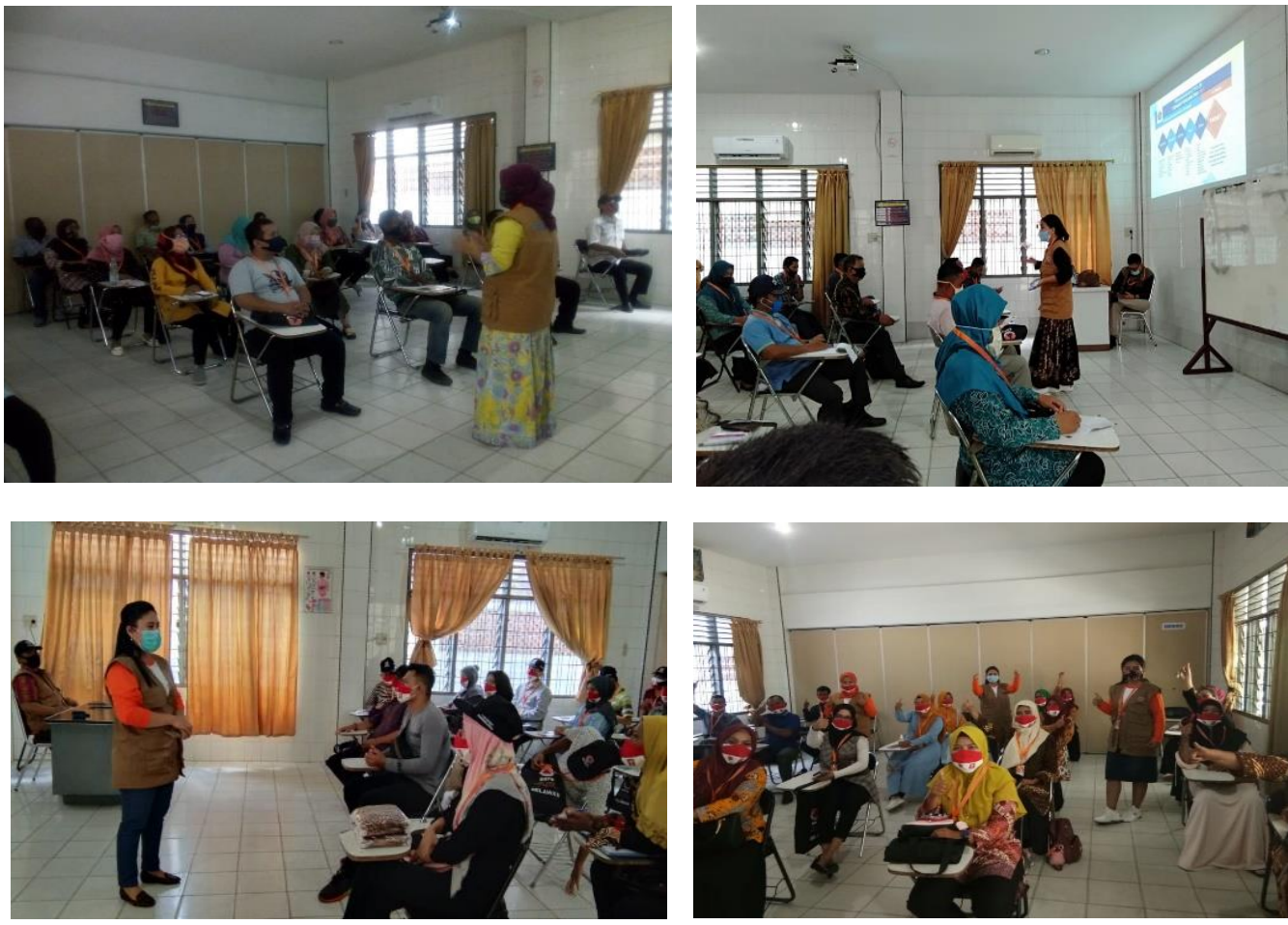

Gambar 4.2 Penyampaian Materi Protokol Kesehatan

\section{b. Pembahasan}

Pemerintah Kota Medan sepakat berkoordinasi untuk percepatan penanganan Covid-19 dan diharapkan dapat menekan laju penyebaran virus corona di Sumut. Secara teknis, upaya yang telah dilakukan Pemerintah di wilayah Medan dalam penanganan Covid-19 adalah menyiapkan fasilitas pelayanan (karantina kesehatan) beserta tenaga kesehatan dengan klasifikasi pasien ringan dan sedang untuk isolasi dan penanganan. Di masingmasing titik perbatasan dibuatkan Posko Penanganan di bawah Gugus Tugas masing-masing kabupaten/kota dengan Gugus Tugas Provinsi sebagai komandan. Kemudian sosialisasi kepada masyarakat serta pendisiplinan masyarakat. Bukan berarti pemerintah daerah itu gagal, tetapi memang masyarakat masih belum disiplin menjalankan protokol kesehatan.

Kegiatan Pengabdian Masyarakat ini adalah guna memutus mata rantai penyebaran Covid-19, yang dilakukan di Gedung USM Indonesia, dimulai terlebih dahulu dengan melakukan pendampingan untuk mengimplementasikan kebijakan strategis Penanganan Covid-19 melalui Pos Gabungan dan Pencegahan (Pos Gagah) dengan memberikan pelatihan kepada utusan dari wilayah Medan yang terdiri dari: Kader Puskesmas, Tokoh Agama, Tokoh Masyarakat dan kelompok Karang Taruna, kemudian peserta pelatihan tersebut akan menjadi agen perubahan. Para agen perubahan tersebut akan menjadi bagian dari skenario besar untuk mengajak semua pihak mematuhi protokol kesehatan, misalnya menggunakan masker, rajin mencuci tangan, dan menjaga jarak sebagai adaptasi kebiasaan baru.

Komitmen awal sangat dibutuhkan dalam pelaksaanan pengabdian ini, karena Komitmen hakikatnya adalah ikhtiar untuk membangun dan memastikan hubungan kerjasama yang produktif serta kemitraan yang harmonis. Pentahelix sebagai persinggungan kesadaran bersama pemerintah dan masyarakat memungkinkan terlaksananya tekad ini, melindungi warga 
yang masih sehat agar tidak tertular penyakit dan semaksimal mungkin menyembuhkan yang telah sakit. Pendekatan berbasis komunitas ini penting untuk menggempur corona dari berbagai sisi. Sekaligus memberikan kejelasan rantai koordinasi dan kendali dalam gugus tugas percepatan penanganan Covid-19.

Corona virus yang terus mewabah di Indonesia, bukan hanya urusan Pemerintah. Bukan juga garapan akademisi maupun kepentingan media semata. Dari aspek regulasi dan kebijakan, itu memang domain pemerintah. Tetapi pada tataran implementasi dan aktualisasi, itu sudah masuk domain masyarakat dengan berbagai karakternya.

Kekuatan untuk melawan corona virus itu juga datang dari dalam diri masyarakat sendiri. Masyarakat lokal mempunyai kearifan-kearifan lokal. Mereka memiliki sumber daya dan spirit lokal. Ini yang mesti diberdayakan, kesadaran masyarakat mesti diberdayakan karena sejatinya mereka mempunyai kesadaran.

Saat ini, mematuhi protokol kesehatan merupakan salah satu cara mengendalikan Covid-19. Oleh karena itu para relawan yang telah dilatih dapat langsung turun memberikan edukasi, mempengaruhi dan meyakinkan masyarakat agar masyarakat dapat mematuhi protokol kesehatan seperti: menggunakan masker saat beraktivitas diluar rumah, mencucui tangan dengan sabun di air mengalir dan menjaga jarak.

Keberadaan relawan adalah wujud nyata semangat kebersamaan dalam penanganan Covid-19. Sebab, penanganan Covid-19 tidak bisa hanya dilakukan oleh pemerintah, namun perlu keterlibatan berbagai pihak yaitu kader puskesmas, akademisi, tokoh agama, tokoh masyarakat dan kelompok karang taruna, kemudian mereka akan menjadi duta perubahan dalam adaptasi kebiasaan baru terkait penerapan protokol kesehatan

\section{KESIMPULAN}

Berdasarkan hasil pelaksanaan kegiatan yang telah dilakukan, dapat ditarik beberapa kesimpulan sebagai berikut;

1. Terjalinnya komitmen dalam membangun kesepakatan, bekerja bersama, saling mendukung dan melengkapi antara pemerintah, akademisi, dunia usaha dan komunitas masyarakat dalam memutus mata rantai penularan Covid-19

2. Melalui pos gagah terbentuknya tim relawan yang akan memperkuat Satgas Covid-19 dalam menegakkan protocol kesehatan melalui edukasi, sosialisasi dan mitigasi.

3. Kegiatan pengabdian yang dilakukan merupakan sebuah kegiatan positif yang bertujuan untuk menghimbau seluruh masyarakat dengan tetap ikut protokoler kesehatan guna rmemutus mata rantai penyebaran Covid-19.

\section{UCAPAN TERIMA KASIH}

a. Kepada Gubernur Sumatera Utara H Edy Rahmayadi Yang telah memberikan ijin sehingga terbentuknya pos pencegahan (Pos Gagah) Copid 19 di Wilayah Sumatera Utara tepatnya di Universitas Sari Mutiara Indonesia

b. Kepada Badan Nasional Penanggulangan Bencana (BNPB) dan Badan Penanggulangan Bencana Daerah (BPBD) Provinsi Sumatera yang telah memberikan dukungan finansial terhadap pelaksanaan kegiatan 
c. Kepada Universitas Sari Mutiara Indonesia yang telah memberikan dukungan fasilitas terhadap pelaksanaan kegiatan

d. Kepada Aparat Kepolisian dan TNI yang telah memberikan dukungan keamanan terhadap pelaksanaan kegiatan

\section{DAFTAR PUSTAKA}

Buana, D. R. (2020). Analisis perilaku masyarakat indonesia dalam menghadapi pandemi virus corona (Covid-19) dan kiat menjaga kesejahteraan jiwa. Salam: Jurnal Sosial dan Budaya Syar-i, 7(3), 217-226, DOI: https://doi.org/10.15408/sjsbs.v7i3.15082 Abstract 0 PDF - 0

Coronavirus Statistics China," accessed April 3, 2020, https: / / www. worldometers.info/coronavirus/country/china/

DEPKES, R. (2020). Pedoman Pencegahan dan Pengendalian Corona Virus Desease.

Di Gennaro, F., Pizzol, D., Marotta, C., Antunes, M., Racalbuto, V., Veronese, N., \& Smith, L. (2020). Coronavirus diseases (COVID-19) current status and future perspectives: a narrative review. International journal of environmental research and public health, 17(8), 2690, DOI:10.3390/ijerph17082690

Firdausi, U., Candra, L. F. K., \& Karma, C. P. F. (2020). Pengabdian Masyarakat dan Anak-Anak Melalui KKN-T Mengenai Edukasi Pencegahan Covid-19 di Desa Dukuh Cikupa. Abdipraja (Jurnal Pengabdian kepada Masyarakat), 1(1), 14-23, DOI: http://dx.doi.org/10.31002/abdipraja.v1i1.3207

Frontiers. (2020). Coronavirus Disease (COVID-19): The Impact and Role of Mass Media During the Pandemic. Di akses pada 9 Agustus 2020 melalui situs web https://www.frontiersin.org/researc htopics/13638/corona virus disease-covid-19-the-impact-androle-ofmass-media during the pandemic

Https://humas.sumutprov.go.id/category/covid-19/

Meihartati, T. (2020). Pentingnya Protokol Kesehatan Keluar Masuk Rumah Saat Pandemi Covid-19 Dilingkungan Masyarakat RT 30 Kelurahan Air Hitam, Samarinda, Kalimantan Timur. Pengabdian Masyarakat, 1(2), http://jurnal.itkeswhs.ac.id/index.php/pengmas/article/view/155

Sulaeman, S., \& Supriadi, S. (2020). Peningkatan pengetahuan masyarakat desa jelantik dalam menghadapi pandemi corona virus diseases-19 (covid-19). Jurnal Pengabdian UNDIKMA: Jurnal Hasil Pengabdian dan Pemberdayaan Kepada Masyarakat, 1(1), https://ejournal.undikma.ac.id

Syapitri, H., Siregar, L. M., \& Saragih, F. L. (2020). Pencegahan Penularan Covid-19 Melalui Sosialisasi Dan Pembagian Masker Di Pasar Pringgan Medan. Jurnal Kreativitas Pengabdian Kepada Masyarakat (Pkm), 3(2), 422-29.

World Health Organization. (2020). Coronavirus disease 2019 (COVID19). Di akses pada 9 Agustus 2020, dari: https://www.who.int/docs/defaultsource/coronaviruse/20200312 